\title{
Determination of Isouron and Its Enaminoketone Metabolite by Thin Layer Chromatography-Densitometry in Hansenula saturnus Metabolism
}

\author{
Mamoru Ozaki and Shozo Kuwatsuka* \\ Aburahi Laboratories, Shionogi Research Laboratories, Shionogi \& Co., Ltd., \\ Koka-cho, Koka-gun, Shiga 520-34, Japan \\ *Faculty of Agriculture, Nagoya University, Chikusa-ku, Nagoya 464, Japan
}

(Received June 19, 1984)

In our previous paper, ${ }^{1,2)}$ it was indicated that isouron was metabolized to 1-(1-amino4,4-dimethyl-3-oxo-1-pentenyl)-3,3-dimethylurea (enaminoketone hereafter) through reductive cleavage of the isoxazole ring. The work was done by the soil perfusion technique. A strain of yeast responsible for this reaction was isolated and identified as Hansenula saturnus. Furthermore, the time-dependence of isouron degradation by cell suspension of the organism was studied qualitatively by thin layer chromatography. The quantitative results of these experiments were insufficient. Fluorometric, ${ }^{3)}$ colorimetric $^{4)}$ and gas chromatographic ${ }^{5)}$ methods for the assay of isouron have been reported. These methods are accurate, but their time consumption is inconvenient if large numbers of samples have to be analyzed. In this study, a method of thin layer chromatography (TLC) and densitometry was applied to the direct determination of both isouron and its metabolite, enaminoketone, for the metabolism by microorganisms. The method was found to be simple and rapid. The degradation of isouron by Hansenula saturnus was analyzed by this method.

\section{MATERIALS AND METHODS}

\section{Chemicals}

Isouron [3-(5-tert-butyl-3-isoxazolyl)-1,1-dimethylurea] and 1-(1-amino-4,4-dimethyl-3oxo-1-pentenyl)-3,3-dimethylurea (enaminoketone) were prepared as described in the previous paper. ${ }^{2)}$

\section{Determination of Isouron and Enamino- ketone by Thin Layer Chromatography and Densitometry}

Silica gel G plate with fluorescent indicator (Merck, Art. 5715) were used for the separation of isouron and enaminoketone. Ten $\mu \mathrm{l}$ of the sample was spotted on the plate, and the plate was developed upward with chloroform-acetone $(30: 5)$. Filter paper moistened with the same solvent was put on the inner walls of the developing cabinet. Development of the plate up to a height of $8 \mathrm{~cm}$ (corresponding to 13-15 min developing time) was sufficient for a reproducible separation of isouron and enaminoketone. The feasibility of the separation on the TLC plate is demonstrated by the profile shown in Fig. 1. The spot of enaminoketone on the TLC was visualized by placing it under a UV-lamp. The quantitative determination of these compounds was achieved by using A Shimadzu-UV-Visible Chromatogram Scanner Model CS-900. The absorbance at the spot on the plate was measured by linear scanning at the wave length of $240 \mathrm{~nm}$ with reflection-absorption photometry. The scanning rate was $20 \mathrm{~mm}$ per min and the dimension of the light beam was $1.0 \times 10.0 \mathrm{~mm}$.

\section{Isouron Degradation by Cell Suspension of Hansenula saturnus}

$H$. saturnus was grown in a modified 


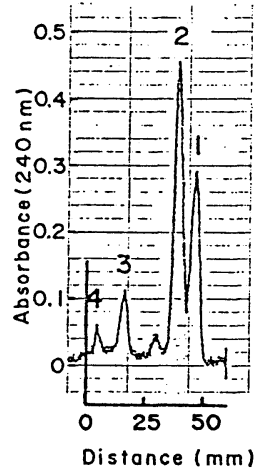

Fig. 1 TLC profile of isouron and enaminoketone.

1: Isouron, 2: Enaminoketone, 3: Metabolite B, 4: Metabolite C.

TLC conditions; Adsorbent: Silica gel G 60 (Merck, Art. 5715), Solvent: Chloroform-acetone (30:5), Developing time: $15 \mathrm{~min}$, Sample volume: $10 \mu \mathrm{l}(0.25-1.5 \mu \mathrm{g})$.

Densitometric conditions; Measuring mode: Reflection-absorption photometry, Wave length: $240 \mathrm{~nm}$, Dimensions of light beam: $1.0 \times 10.0$ $\mathrm{mm}$, Scanning rate: $20 \mathrm{~mm} / \mathrm{min}$.

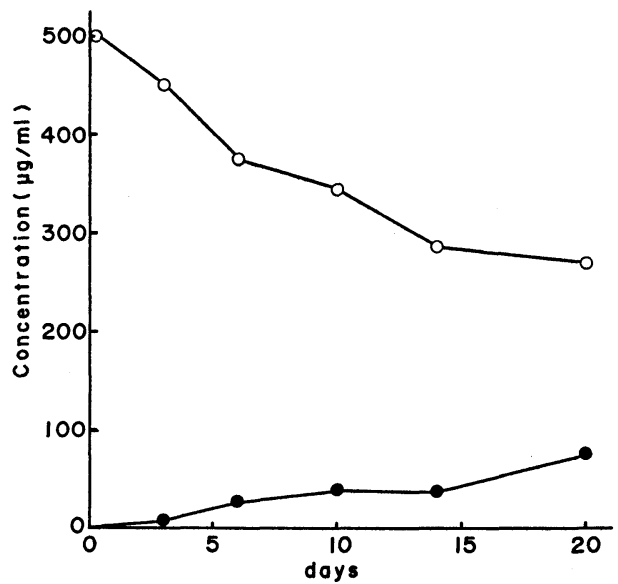

Fig. 2 Degradation of isouron by cell suspension of Hansenula saturnus.

$\bigcirc$ : isouron, 9 : enaminoketone.

The cell suspension was incubated with $500 \mu \mathrm{g}$ of isouron per $\mathrm{ml}$ at $28^{\circ} \mathrm{C}$.

Sabourauds' agar medium $(4.0 \%$ glucose, $1.0 \%$ polypeptone, $0.5 \%$ yeast extract and $1.5 \%$ agar) at $28^{\circ} \mathrm{C}$ for 3 days. The cells were collected and washed twice with $0.06 \mathrm{~m}$ phosphate
Table $1 \quad R f$ values of isouron and enaminoketone in various solvent systems.

\begin{tabular}{lcc}
\hline \multicolumn{1}{c}{ Solvent } & \multicolumn{2}{c}{$R f$ values } \\
\cline { 2 - 3 } & Isouron & $\begin{array}{c}\text { Enamino- } \\
\text { ketone }\end{array}$ \\
\hline Ethyl ether & 0.34 & 0.37 \\
Ethyl ether-hexane $(7: 3)$ & 0.20 & 0.24 \\
Isopropyl alcohol-hexane & 0.64 & 0.70 \\
$\quad(1: 1)$ & & \\
Chloroform-acetone $(1: 1)$ & 0.53 & 0.48 \\
Chloroform-acetone $(30: 5)$ & 0.54 & 0.47 \\
Chloroform-methyl alcohol & 0.48 & 0.43 \\
$\quad$ (9:1) & 0.36 & 0.32 \\
Chloroform & &
\end{tabular}

TLC conditions were the same as those shown in Fig. 1 .

buffer ( $\mathrm{pH} 7.0)$. The washed cells were resuspended in the buffer to give $20 \mathrm{mg}$ dry weight of cells per $\mathrm{ml}$. Isouron was then added to the suspension, which was incubated at $28^{\circ} \mathrm{C}$. One $\mathrm{ml}$ of the suspension was periodically collected for the determination of isouron and enaminoketone.

\section{Extraction of Isouron and Enaminoketone}

The cell suspension collected was centrifuged at $1500 \mathrm{~g}$ for $15 \mathrm{~min}$. The supernatant was separated, saturated with $\mathrm{NaCl}$, and one $\mathrm{ml}$ of ethyl acetate-benzene $(3: 1)$ was added to it. The entire sample was stirred for a few minutes by a mixer and centrifuged again at $1500 \mathrm{~g}$ for $3 \mathrm{~min}$. The organic solvent phase was collected. This extraction procedure was repeated twice. The total extracts were combined and concentrated to dryness by rotary evaporator under reduced pressure. The residue was dissolved in one $\mathrm{ml}$ of the solvent mixture mentioned above and ten $\mu \mathrm{l}$ of the solution was subjected to TLC using a microsyringe.

\section{RESULTS AND DISCUSSION}

Two solvents and six solvent mixtures were evaluated for their capability of separating isouron and enaminoketone on TLC plates (Table 1). The solvent mixture of chloroformacetone $(30: 5)$ was found to be best suited for this purpose and was chosen for further studies. As indicated in Fig. 1, the spot of 
enaminoketone was located below that of isouron, and could be recognized with UVlamp. The absorption maximum of isouron was at $239 \mathrm{~nm}$, whereas those of enaminoketone were at $240 \mathrm{~nm}$ and $305 \mathrm{~nm}$. The absorbance of both compounds on the plate could be measured simultaneously by scanning from the front edge to the starting point at a wave length of $240 \mathrm{~nm}$. The calibration curves of isouron and enaminoketone were linear in the range of $0.25-1.5 \mu \mathrm{g} / \mathrm{spot}$ according to the regression equations $y=0.176 x+$ 0.03 for isouron and $y=0.176 x+0.02$ for enaminoketone. The detection limits of these compounds were $0.05 \mu \mathrm{g}$. The correlation ratio determined by the least-squares method was more than $99 \%$ for both curves. The coefficients of variation for the determination of isouron and enaminoketone amounted to the averaged values of $2.5 \%$ and $3.3 \%(n=5)$, respectively. By repeated determinations of sample solutions at a constant concentration $(100 \mu \mathrm{g} / \mathrm{ml})$ by this method, the overall recoveries of isouron and enaminoketone were $92.3 \pm 3.43 \%$ and $91.8 \pm 4.06 \% \quad(n=10)$, respectively. The result indicated that the assay outlined above can be used as a simple and rapid method to analyze large numbers of samples.

The degradation of isouron to enaminoketone by a cell suspension of $H$. saturnus was studied quantitatively by this assay. The result is shown in Fig. 2. Isouron was metabolized gradually and $40 \%$ of the initial concentration disappeared after 20 days of incubation. Enaminoketone was formed as the main metabolite in the cell suspension while isouron was degraded, and the concentration of the metabolite was increased to $75 \mu \mathrm{g} / \mathrm{ml}$. The results indicated that the time-dependence of isouron degradation by $H$. saturnus could be analyzed quantitatively with the assay by thin layer chromatography and densitometry, and the organism has the capability of degrading isouron to enaminoketone by reductive cleavage of the isoxazole ring.

\section{ACKNOWLEDGEMENTS}

The authors wish to thank Dr. Y. Hayashi, Director of Aburahi Laboratories, Shionogi \& Co., Ltd., for his encouragement through the course of this study.

\section{REFERENCES}

1) Y. Hayase, M. Ozaki, S. Kobayashi \& Y. Takeuchi: J. Pesticide Sci. 7, 401 (1982)

2) M. Ozaki, Y. Hayase, S. Kobayashi \& S. Kuwatsuka: J. Pesticide Sci. 9, 285 (1984)

3) K. Iwakura, T. Kitagawa \& E. Hirai: $J$. Pharm. Sci. Jpn. 101, 527 (1981)

4) T. Kitagawa, K. Iwakura \& E. Hirai: Chem. Pharm. Bull. 29, 2303 (1981)

5) Y. Hayase, K. Nakajima, S. Kobayashi \& T. Takahashi: J. Pesticide Sci. 7, 195 (1982)

\section{要約}

薄層クロマトグラフィー・デンシトメトリーに よるイソウロンおよびェナミノケトンの定量と Hansenula saturnus によるイソウロンの分解 過程

尾崎 守, 鍬塚昭三

薄層クロマトグラフィー(TLC) とリニアスキャンニン グ方式の TLC スキャナーを用いるデンシトメトリーに よって除草剂イソウロンとその代謝物エナミノケトンの 分離と定量を行なった。吸着剂としてシリカゲルを用 い,クロロホルムーアセトン (30:5) の混合溶媒で展開す ると両化合物は良好に分離した，これをTLC スキャナ 一を用いて波長 $240 \mathrm{~nm}$ における吸光度で測定すると兩 化合物の量と吸光度の間には $0.25 \sim 1.5 \mu \mathrm{g} / \mathrm{spot}$ の範囲 で直線関係が成立した。この定量法を用いてHansenula saturnus によるイソウロンの分解を調べた，イソウ口 ンは徐々に分解し 20 日目には初濃度の $40 \%$ が消失した。 それに対応してエナミノケトンが生成し培地中に蓄積し た. 